\section{Responses of Native Australian Cut Flowers to Treatment with 1-Methylcyclopropene and Ethylene}

\author{
Andrew J. Macnish and David H. Simons \\ School of Land and Food, The University of Queensland, Gatton College, Qld. \\ 4345, Australia
}

Daryl C. Joyce ${ }^{1}$

Silsoe College, Cranfield University, Silsoe, Bedford MK45 4DT, United Kingdom

\section{John D. Faragher \\ Institute for Horticultural Development, Private Bag 15, South Eastern Mail Centre, Vic 3176, Australia}

Peter J. Hofman

Queensland Department of Primary Industries, PO Box 5083, Sunshine Coast Mail Centre, Qld 4560, Australia

Additional index words. abscission, Cassinia adunca, Ceratopetalum gummiferum, Chamelaucium uncinatum, Eriostemon scaber, Grevillea, Leptospermum petersonii, Leptospermum scoparium, Ozothamnus diosmifolius, Platysace lanceolata, senescence, silver thiosulfate, Telopea, Thryptomene calycina, vase life, Verticordia nitens, Zieria cytisoides

\begin{abstract}
Postharvest longevity of some cut flowers is shortened by exposure to ethylene gas. Adverse effects of ethylene may be prevented by treatment with 1-methylcyclopropene (1-MCP) gas. Responses of 14 different native Australian cut flowers to 1-MCP and ethylene applied at concentrations of $10 \mathrm{~nL} \cdot \mathrm{L}^{-1}$ and $10 \mu \mathrm{L} \cdot \mathrm{L}^{-1}$, respectively, were examined. Each gas was applied alone for 12 hours at $20^{\circ} \mathrm{C}$ and they were also applied in series. Vase lives of Ceratopetalum gummiferum, Chamelaucium uncinatum, Grevillea 'Kay Williams' and 'Misty Pink', Leptospermum petersonii, Telopea 'Shady Lady', and Verticordia nitens were reduced by ethylene treatment. Treatment with 1-MCP generally protected these cut flowers against subsequent exposure to ethylene. The 1-MCP treatment usually did not extend their vase lives in the absence of exogenous ethylene.
\end{abstract}

Native Australian cut flowers are traded internationally (e.g., Australian Bureau of Statistics, 1998). However, unless treated with silver thiosulphate (STS), floral organ abscission or senescence occurs in some Australian flowers on exposure to ethylene, thereby reducing vase life and marketability (Joyce et al., 1993). Despite environmental risks, STS is used commercially (Serek et al., 1994). Alternatively, the novel, gaseous, ethylene-binding inhibitor, 1-MCP (1-methylcyclopropene), can protect cut flowers (Serek et al., 1995a, 1995b; Sisler et al., 1996). In this screening study, the efficacy of 1-MCP treatment in preventing

Received for publication 12 Apr. 1999. Accepted for publication 30 June 1999. We thank the Rural Industries Research and Development Corporation for financial support, Mr. Tony Slater for experimental assistance and advice, and Mr. Allan Lisle for statistical advice. The cost of publishing this paper was defrayed in part by the payment of page charges. Under postal regulations, this paper therefore must be hereby marked advertisement solely to indicate this fact.

${ }^{1}$ To whom reprint requests should be addressed; email: d.joyce@cranfield.ac.uk ethylene damage to a range of native Australian flowers was examined.

\section{Materials and Methods}

Cut Verticordia nitens (Lindley) Schauer (yellow morrison) flowers and flowering Ceratopetalum gummiferum (Smith) (New South Wales Christmas bush) stems were received at the Queensland laboratory within 48 $\mathrm{h}$ of harvest. Other flowers, Cassinia adunca (Sonder), Platysace lanceolata (Labill.) Druce, Grevillea 'Misty Pink' and 'Kay Williams', Chamelaucium uncinatum (Schauer) 'Paddy's Late' (Geraldton waxflower), Leptospermum petersonii (Bailey) (lemon-scented tea tree), Ozothamnus diosmifolius (Vent.) DC 'Cooks Tall Pink' (rice flower), and Zieria cytisoides (Smith) were taken to this laboratory within 3 $\mathrm{h}$ of harvest. Flowering Eriostemon scaber (Paxton) and Thryptomene calycina (Lindley) Stapf. (Grampians thryptomene) stems and Telopea 'Shady Lady' inflorescences were taken to the Victorian laboratory within $24 \mathrm{~h}$ of harvest. Flowering Leptospermum scoparium (Forster) 'Winter Cheer' (tea tree) stems were harvested from plants growing near this labo- ratory. Descriptions of these genera can be found in Wrigley and Fagg (1997).

Flowers were assigned to individual vases containing $10 \mathrm{mg}$ available chlorine per liter of deionized water. The 1-MCP gas was synthesized and quantified according to Sisler and Serek (1997). Flowers were treated on day 0 with 0 or $10 \mathrm{~nL} \cdot \mathrm{L}^{-1} 1-\mathrm{MCP}$ for $12 \mathrm{~h}$ at $20^{\circ} \mathrm{C}$ inside sealed glass or perspex chambers. Half of the flowers from each of these treatments were then exposed on day 1 to ethylene (10 $\left.\mu \mathrm{L} \cdot \mathrm{L}^{-1}\right)$ for $12 \mathrm{~h}$ at $20^{\circ} \mathrm{C}$. The $1-\mathrm{MCP}$ treatment protocol was chosen on the basis of preliminary experiments with Grevillea 'Sylvia' (Setyadjit et al., 1997) and other cut flowers (Serek et al., 1995a), in which this treatment provided protection against ethylene. The ethylene treatment protocol was based on similar treatments reported by Joyce (1989), which caused flower abscission in C. uncinatum. All flowers were held at $20 \pm 2{ }^{\circ} \mathrm{C}, 50 \%$ to $70 \%$ relative humidity under a 12 -h light period per day $\left(10-13 \mu \mathrm{mol} \cdot \mathrm{m}^{-2} \cdot \mathrm{s}^{-1}\right)$. Completely randomized designs were used with five to 10 replicate flowers per treatment. Data were analyzed by analysis of variance as $2 \times 2$ factorials using MINITAB Release 11.12.

\section{Results and Discussion}

Nanomolar concentrations of 1-MCP prevented floral organ abscission (data not presented) and associated loss in vase life in $C$. gummiferum, C. uncinatum, Grevillea 'Kay Williams', Grevillea 'Misty Pink', L. petersonii, and $V$. nitens following treatment with exogenous ethylene (Table 1). This finding is consistent with reports that STS treatment prevents ethylene-related abscission in cut flowers of $C$. uncinatum, $V$. nitens, and Grevillea hybrids (Joyce, 1989; Joyce and Poole, 1993; Joyce et al., 1993; respectively). The 1-MCP treatment did not provide significant protection against ethylene for Telopea 'Shady Lady'. Vase lives of C. adunca, E. scaber, L. scoparium, $O$. diosmifolius, $P$. lanceolata, $T$. calycina, and Z. cytisoides were not significantly $(P>0.05)$ reduced by exposure to exogenous ethylene. Except for $C$. gummiferum, 1-MCP treatment did not significantly $(P>0.05)$ extend the vase life of any of the other 13 species tested when they were not exposed to ethylene.

This study shows that 1-MCP gas, which is easy to apply, has potential as a postharvest anti-ethylene treatment for C. gummiferum, $C$. uncinatum, Grevillea 'Kay Williams', Grevillea 'Misty Pink', L. petersonii, and V. nitens.

\section{Literature Cited}

Australian Bureau of Statistics. 1998. Exports by industry, p. 83. Austral. Bur. Stat., Canberra, Australia.

Joyce, D., R. Jones, and J. Faragher. 1993. Postharvest characteristics of native Australian flowers. Postharvest News and Inform. 4:61N-67N.

Joyce, D.C. 1989. Treatments to prevent flower abscission in Geraldton wax. HortScience 24:391.

Joyce, D.C. and M.C. Poole. 1993. Effects of ethyl- 
Table 1. Effect of 1-MCP and ethylene ${ }^{\mathrm{x}}$ on vase lives ${ }^{\mathrm{y}}$ of Australian native cut flowers. ${ }^{\mathrm{z}}$

\begin{tabular}{|c|c|c|c|c|c|}
\hline \multirow[b]{3}{*}{ Species } & \multirow[b]{3}{*}{ 1-MCP $\left(\mathrm{nL} \cdot \mathrm{L}^{-1}\right)$} & \multicolumn{3}{|c|}{ Ethylene $\left(\mu \mathrm{L} \cdot \mathrm{L}^{-1}\right)$} & \multirow[b]{3}{*}{ Vase life termination criteria ${ }^{y}$} \\
\hline & & 0 & \multicolumn{2}{|c|}{10} & \\
\hline & & 10 & 0 & 10 & \\
\hline Ceratopetalum gummiferum & $11.2 \mathrm{~b}$ & $15.6 \mathrm{c}$ & $4.9 \mathrm{a}$ & $14.8 \mathrm{~b}$ & Flower abscission and/or sepal wilting \\
\hline Chamelaucium uncinatum & $11.1 \mathrm{~b}$ & $11.5 \mathrm{~b}$ & $1.0 \mathrm{a}$ & $10.7 \mathrm{~b}$ & Flower abscission and/or closing \\
\hline Cassinia adunca & $6.7 \mathrm{a}$ & $4.8 \mathrm{a}$ & $5.5 \mathrm{a}$ & $7.0 \mathrm{a}$ & Leaf senescence and/or pedicel wilting \\
\hline Eriostemon scaber & $2.9 \mathrm{a}$ & $3.4 \mathrm{a}$ & $3.0 \mathrm{a}$ & $3.3 \mathrm{a}$ & Petal abscission \\
\hline Grevillea 'Kay Williams' & $4.1 \mathrm{~b}$ & $4.4 \mathrm{~b}$ & $1.0 \mathrm{a}$ & $4.3 \mathrm{~b}$ & Flower abscission and/or wilting and/or fading \\
\hline Grevillea 'Misty Pink' & $4.1 \mathrm{~b}$ & $4.1 \mathrm{~b}$ & $1.0 \mathrm{a}$ & $3.9 \mathrm{~b}$ & Flower abscission and/or wilting and/or fading \\
\hline Leptospermum petersonii & $2.5 \mathrm{~b}$ & $3.0 \mathrm{~b}$ & $1.4 \mathrm{a}$ & $3.4 \mathrm{~b}$ & Flower abscission and/or closing \\
\hline Leptospermum scoparium & $2.8 \mathrm{ab}$ & $3.4 \mathrm{~b}$ & $2.6 \mathrm{a}$ & $3.0 \mathrm{ab}$ & Flower abscission and/or wilting and/or fading \\
\hline Ozothamnus diosmifolius & $7.1 \mathrm{a}$ & $5.5 \mathrm{a}$ & $5.3 \mathrm{a}$ & $7.0 \mathrm{a}$ & Leaf senescence and/or pedicel wilting \\
\hline Platysace lanceolata & $20.4 \mathrm{a}$ & $19.3 \mathrm{a}$ & $18.5 \mathrm{a}$ & $20.1 \mathrm{a}$ & Flower wilting and/or fading \\
\hline Thryptomene calycina & $3.6 \mathrm{~b}$ & $3.0 \mathrm{ab}$ & $3.0 \mathrm{ab}$ & $2.6 \mathrm{a}$ & Flower closing \\
\hline Telopea 'Shady Lady' & $2.3 \mathrm{~b}$ & $2.5 \mathrm{~b}$ & $1.3 \mathrm{a}$ & $2.2 \mathrm{ab}$ & Perianth abscission \\
\hline Verticordia nitens & $11.0 \mathrm{~b}$ & $9.8 \mathrm{~b}$ & $1.0 \mathrm{a}$ & $11.3 \mathrm{~b}$ & Flower abscission and/or closing and/or fading \\
\hline Zieria cytisoides & $3.6 \mathrm{a}$ & $4.8 \mathrm{a}$ & $2.6 \mathrm{a}$ & $4.4 \mathrm{a}$ & Flower abscission and/or wilting \\
\hline
\end{tabular}

${ }^{\mathrm{z}}$ Mean separation within rows by LSD, $P \leq 0.05$.

${ }^{\mathrm{y}}$ Subjectively assessed as loss of visual appeal.

${ }^{\mathrm{x}} 1-\mathrm{MCP}$ and ethylene were each applied for $12 \mathrm{~h}$ at $20^{\circ} \mathrm{C}$ on day 0 and 1 , respectively.

ene and dehydration on cut flowering stems of Verticordia spp. Austral. J. Expt. Agr. 33:489493.

Serek, M., M.S. Reid, and E.C. Sisler. 1994. A volatile ethylene inhibitor improves the postharvest life of potted roses. J. Amer. Soc. Hort. Sci. 119:572-577.

Serek, M., E.C. Sisler, and M.S. Reid. 1995a. Effects of 1-MCP on the vase life and ethylene response of cut flowers. Plant Growth Regulat. 16:93-97.
Serek, M., E.C. Sisler, T. Tirosh, and S. Mayak. 1995b. 1-Methylcyclopropene prevents bud, flower, and leaf abscission of Geraldton waxflower. HortScience 30:1310.

Setyadjit, A.J. Macnish, D.C. Joyce, and D.H. Simons. 1997. 1-Methylcyclopropene prevents ethylene-mediated flower abscission from Grevillea 'Sylvia' inflorescences, p. 333-335. In: Proc. Australasian Postharvest Hort. Conf., 28 Sept.-3 Oct. 1997, Univ. of Western Sydney, Hawkesbury, Australia.
Sisler, E.C., E. Dupille, and M. Serek. 1996. Effect of 1-methylcyclopropene and methylenecyclopropene on ethylene binding and ethylene action on cut carnations. Plant Growth Regulat. 18:79-86.

Sisler, E.C. and M. Serek. 1997. Inhibitors of ethylene responses in plants at the receptor level: recent developments. Physiol. Plant. 100:577-582.

Wrigley, J.W. and M. Fagg. 1997. Australian native plants. 4th ed. Reed Books, Kew, Australia. 